\title{
Guided Insertion of Temporary Anchorage Device in Form of Orthodontic Titanium Miniscrews with Customized 3D Templates-A Systematic Review with Meta-Analysis of Clinical Studies
}

\author{
Maciej Jedliński 1,2,*(D), Joanna Janiszewska-Olszowska ${ }^{1, * \mathbb{D}}$, Marta Mazur ${ }^{2}\left(\mathbb{D}\right.$, Livia Ottolenghi ${ }^{2} \mathbb{D}$, \\ Katarzyna Grocholewicz ${ }^{1}$ (D) and Gabriella Galluccio ${ }^{2}$ (D)
}

1 Department of Interdisciplinary Dentistry, Pomeranian Medical University in Szczecin, 70-111 Szczecin, Poland; katgro@pum.edu.pl

2 Department of Dental and Maxillofacial Sciences, Sapienza University of Rome, 00161 Rome, Italy; marta.mazur@uniroma1.it (M.M.); livia.ottolenghi@uniroma1.it (L.O.); gabriella.galluccio@uniroma1.it (G.G.)

* Correspondence: maciej.jedlinski@pum.edu.pl (M.J.); jjo@pum.edu.pl (J.J.-O.)

\section{check for updates \\ Citation: Jedliński, M.; Janiszewska-Olszowska, J.; Mazur, M.; Ottolenghi, L.; Grocholewicz, K.; Galluccio, G. Guided Insertion of Temporary Anchorage Device in Form of Orthodontic Titanium Miniscrews with Customized 3D Templates-A Systematic Review with Meta-Analysis of Clinical Studies. Coatings 2021, 11, 1488. https://doi.org/10.3390/ coatings 11121488}

Academic Editor: Devis Bellucci

Received: 10 November 2021 Accepted: 30 November 2021 Published: 2 December 2021

Publisher's Note: MDPI stays neutral with regard to jurisdictional claims in published maps and institutional affiliations.

Copyright: ( $\odot 2021$ by the authors Licensee MDPI, Basel, Switzerland. This article is an open access article distributed under the terms and conditions of the Creative Commons Attribution (CC BY) license (https:// creativecommons.org/licenses/by/ $4.0 /)$.
Abstract: (1) Background: Miniscrew insertion, using a surgical guide, aims to avoid possible adverse effects or complications. With the higher availability of both 3D imaging and printing, 3D surgical guides have been used more frequently in orthodontics. The aim of the present systematic review was to find scientific clinical evidence concerning the precision of the 3D guided insertion of miniscrews for temporary orthodontic anchorage. (2) Methods: Literature searches were performed in the following five search engines: Pubmed (Medline), Pubmed Central, Scopus, Web of Science and Embase on 10 September 2021 (articles from 1950 to 10 September 2021). A meta-analysis was performed using the random-effect model, with Standardized Mean Differences (SMD) and 95\% confidence intervals (95\% CI) calculated as effect estimates. The heterogeneity was assessed quantitatively. (3) Results: The search strategy identified 671 potential articles. After the removal of duplicates, 530 articles were analyzed. Subsequently, 487 papers were excluded, because they were not associated with the subject of the study. Of the remaining 43 papers, 34 were excluded because they did not meet the methodological criteria. Finally, only nine papers were subjected to a qualitative analysis. (4) Conclusions: The current literature concerning guided miniscrew insertion reveals, for the most part, a low methodological level. High-quality clinical trials are in the minority. The use of surgical guides increases insertion accuracy, stability and reduces the failure rate of orthodontic miniscrews. Tooth-borne insertion guides supported on the edges of the teeth ensure a higher insertion precision compared to mucosa-borne ones. The study protocol was registered in PROSPERO under the number CRD42021267248.

Keywords: guided insertion; surgical guide; orthodontics; mini-implant; temporary anchorage device; TAD; accuracy; precision

\section{Introduction}

Orthodontic mini-implants (MIs), also called temporary anchorage devices (TADs), have been considered to be effective tools for intraoral anchorage reinforcement for many years [1]. Their main advantages are their easy application, the possibility to use them at various stages of treatment and the predictability of biomechanical effects [2]. The first scientifically documented attempts to use orthodontic mini-implants date back to 1945 [3]. Even then, attention was paid to the fact that insertion procedures may cause complications. Studies on adverse effects or complications concurrent to the application of miniscrews are scarce and present a low methodological quality [3]. However, it has been proved that complications due to the incorrect introduction of MI may lead to root injury and 
periradicular lesion, of the buccal mucosa, or insertion into maxillary sinus or nasal floor (causing loss of vitality, pink discoloration or transitory loss of pulp sensitivity) [4-6].

Optimal positioning of the screw, taking into account root proximity [7], bone support as well as soft tissue thickness and quality, intends to avoid most complications [8]. For this purpose, surgical templates were introduced. In the glossary of prosthodontic terms, a surgical template is defined as a guide used to assist in the proper surgical placement and angulation of dental implants [9]. The main purpose of the surgical template is to direct drilling and ensure accurate implant placement according to the treatment plan. In order to accurately transfer the implant directly the surgical site, custom surgical templates based on radiological diagnostics have become the treatment of choice [10]. Miniscrew insertion using a surgical guide aims to avoid possible adverse effects or complications. A significant reduction of the failure rate was noticed when using detailed radiological diagnostics of the insertion site, nevertheless a two-dimensional X-ray is considered as sufficient for routine procedures [11]. However, some authors are of the opinion that it is necessary to perform CBCT on or before placing TADs in patients with severe space deficiency, significant tooth crowding, or extraordinary root position on panoramic radiographs [12]. At the turn of the century, wire guides, based on a periapical X-ray gained popularity [13], and they have been used successfully until now by many clinicians, especially if advanced diagnostic tools are unavailable [14]. With the higher availability of both 3D imaging and printing, 3D surgical guides, for which the effectiveness has been well documented in implantology, they have been used more frequently $[15,16]$. For many clinicians, they seem to present a new avenue, and are even seen as a new remedy for possible complications that may occur during MI insertion. However, they do not take into account key factors such as lack of operator experience, manufacturing costs of template fabrication, the influences of which have already been examined in the case of prosthetic dental implants $[17,18]$. Therefore, it seems justified to examine the validity of surgical-templates use, which may contribute a discussion on other aspects of guided insertion of temporary anchorage in orthodontics.

Numerous technical papers and case reports describing different systems for guided insertion of orthodontic miniscrews have been published in the last two decades [19-24]. Their authors try to ascertain both the accuracy and clinical effectiveness of various solutions, including 3D solutions. The aim of the present systematic review was to find scientific clinical evidence concerning the precision of 3D guided insertion of minis-crews for temporary orthodontic anchorage.

\section{Materials and Methods}

\subsection{Search Strategy}

This systematic review was conducted in accordance with the PRISMA statement (as shown in the Supplementary Materials) [25], the PRISMA reporting guidelines [26,27] and the Cochrane Handbook for Systematic Reviews of Interventions [28]. Literature searches were performed in across the following five search engines: Pubmed (Medline), Pubmed Central, Scopus, Web of Science and Embase on 10 September 2021. All searches were performed using a combination of subject headings and free-text terms, and the final search strategy was determined through several pre-searches. The keywords used in the search strategy were as follows: ("guided insertion" OR "guided surgical procedure" OR "surgical guide" OR "guided placement" OR "guided positioning") AND ("mini-implant" OR "miniscrew" OR "TAD" OR "temporary anchorage device") AND “orthodontics". The study protocol was registered in PROSPERO database with the number CRD42021267248. The framework of this systematic review according to PICO [29] was as follows: Population: orthodontic patients; Intervention: 3D guided miniscrew insertion; Comparison: different protocols of guided orthodontic miniscrew insertion applied; Outcomes: accuracy, efficacy. The PICO question proposed was as follows: "In orthodontic patients does 3D guided miniscrew insertion, compared with different protocols (wire guide, manual insertion with digital planning), allow more accurate and effective miniscrew placement?". 


\subsection{Eligibility Criteria}

The following inclusion criteria were applied for this systematic review:

(1) Type of study: Quantitative randomized controlled clinical trials and quantitative nonrandomized clinical studies.

(2) Results of the study: Accuracy of 3D guided orthodontic miniscrew insertion in comparison to other methods.

(3) Objective of the study: Comparison of the efficacy and accuracy of guided orthodonticminiscrew insertion procedure to standard procedure.

(4) Subject of the study: human subjects.

The following exclusion criteria were applied: reviews, incomplete studies (e.g., lack of control group), case reports, lack of effective statistical analysis; papers not related to guided miniscrew insertion, descriptions of the technique, studies not written in English.

\subsection{Data Extraction}

Titles and abstracts were independently selected by two authors (M.J. and J.J.-O.), following the inclusion criteria. The full text of each identified article was then analyzed to verify suitability for inclusion. Whenever disagreements occurred, they were resolved by discussions with the third author (G.G.), and by creating a worksheet in order to compare decisions in accordance with the Cochrane Collaboration guidelines [28]. The Cohen's $\mathrm{K}$ coefficient for the agreement between the authors was almost perfect and was of the value of 0.98 . Authorship, year of publication, type of each eligible study and its relevance regarding the guided insertion of mini-implants with 3D guiding templates were extracted by one author (M.J.) and examined by another author (M.M.).

\subsection{Quality Assessment}

According to the PRISMA statements, the evaluation of methodological quality provides an indication of the strength of evidence included in th study because methodological flaws can result in biases [25]. Due to the wide range of types of studies which were finally included in this systematic review we decided to use the Mixed Methods Appraisal Tool (MMAT) [30]. This tool consists of the following two parts: checklist (Part I) and explanation of the criteria (Part II). The possible responses for all questions were: 'Yes', 'No' or 'Can't Tell'. The response 'No' to two of the screening questions or 'Can't tell' to one or both the screening questions might indicate that the paper cannot be appraised using the MMAT. Positive responses indicate a high quality of evidence presented in the study, while "Can't tell" indicates a failure to report exact results that meet the assumptions of the question. A quality assessment was independently carried out by two authors (M.J. and M.M.). We planned to discuss possible differences in the evaluation of the quality of the studies through discussion, but the authors assessed the quality of the studies in identical ways.

\subsection{Meta-Analysis}

A meta-analysis was performed using the random-effect model via metafor and compute.es $R$ packages [31], with Standardized Mean Differences (SMD) and 95\% confidence intervals $(95 \% \mathrm{CI})$ calculated as the effect estimates. Heterogeneity was assessed quantitatively using $I^{2}$-statistics and Cochrane's Q [32]. In cases where there were reported ranges instead of standard deviations, the range rule [33] was used to estimate standard deviations for use in this study. Publication biases were estimated using a funnel plot.

\section{Results}

\subsection{Search Results}

The search strategy identified 671 potential articles, including 72 from PubMed and PubMed Central, 155 from Scopus, 14 from Web of science, 2 from Embase and 428 from Google Scholar. After the removal of duplicates, 530 articles were analyzed. Subsequently, 487 papers were excluded because they did not meet the inclusion criteria. Of the remaining 
43 papers, 34 were excluded because they were not relevant to the subject of the study (mainly about wire guided insertion or without proper statistical analysis). The excluded articles were mainly descriptions of techniques, case reports, case series or other papers that lacked an effective statistical analysis. Thus, only 9 papers were subjected to a qualitative analysis. A Prisma 2020 Flow Diagram representing the study selection process is presented in Figure 1. (Figure 1. Flow diagram) The main characteristics included of each study are presented in Table 1.

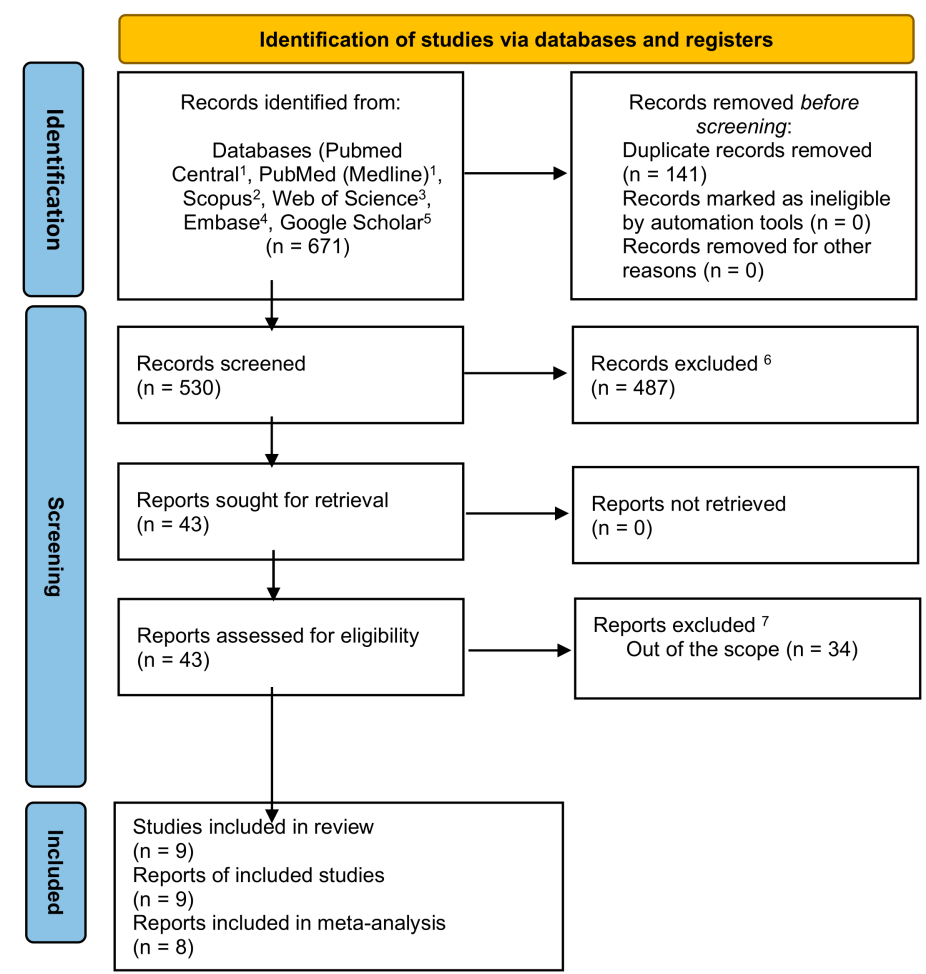

1 - search string: ("guided insertion" OR "guided surgical procedure" OR "surgical guide" OR "guided placement" OR "guided positioning") AND ("mini-implant" OR "miniscrew" OR "TAD" OR "temporary anchorage device") AND "orthodontics"

2 - search string: ALL ( ( "guided insertion" OR "guided surgical procedure" OR "surgical guide" OR "guided placement" OR "guided positioning") AND ( "mini-implant" OR "miniscrew" OR "TAD" OR "temporary anchorage device" ) AND "orthodontics" ) AND ( LIMIT-TO ( DOCTYPE, "ar" ))

3 - search string: ("guided insertion" OR "guided surgical procedure" OR "surgical guide" OR "guided placement" OR "guided positioning") AND ("mini-implant" OR "miniscrew" OR "TAD" OR "temporary anchorage device") AND "orthodontics" WEB OF SCIENCE CATEGORIES: ( DENTISTRY ORAL SURGERY MEDICINE )

4 - search string: ('guided insertion' OR 'guided surgical procedure' OR 'surgical guide' OR 'guided placement' OR 'guided positioning') AND ('mini-implant' OR 'miniscrew'/exp OR 'miniscrew' OR 'tad' OR 'temporary anchorage device'/exp OR 'temporary anchorage device') AND ('orthodontics'/exp OR 'orthodontics') AND [embase]/lim NOT ([embase]/lim AND [medline]/lim)

5 - search string: ("guided insertion" OR "guided surgical procedure" OR "surgical guide" OR "guided placement" OR "guided positioning") AND ("mini-implant" OR "miniscrew" OR "TAD" OR "temporary anchorage device") AND "orthodontics"

${ }^{6}$ - incomplete studies, reviews, in-vitro studies, papers not related to guided TAD insertion, studies not written in English.

${ }^{7}$ - because of the lack of effective statistical analysis, description of the technique, case reports

Figure 1. Search strategy_Prisma 2020 flow diagram. 
Table 1. Characteristics of included studies.

\begin{tabular}{|c|c|c|c|c|c|c|}
\hline $\begin{array}{c}\text { Author and } \\
\text { Year }\end{array}$ & $\begin{array}{l}\text { Type of } \\
\text { Article }\end{array}$ & $\begin{array}{l}\text { Material or } \\
\text { Subjects }\end{array}$ & $\begin{array}{l}\text { Control } \\
\text { Sample or } \\
\text { Group }\end{array}$ & Method & $\begin{array}{l}\text { Outcome } \\
\text { Measured }\end{array}$ & Results \\
\hline $\begin{array}{c}\text { Suzuki and } \\
\text { Suzuki, } 2007 \\
\text { [34] }\end{array}$ & $\begin{array}{c}\text { Case-control } \\
\text { study }\end{array}$ & $\begin{array}{l}180 \text { implants } \\
\text { inserted with } \\
\text { the use of a 3D } \\
\text { surgical guide }\end{array}$ & $\begin{array}{l}\text { (a) } 20 \text { implants } \\
\text { inserted using } \\
\text { a conventional } \\
\text { wire guide } \\
\text { (b) } 20 \text { implants } \\
\text { inserted } \\
\text { without any } \\
\text { guide }\end{array}$ & $\begin{array}{l}\text { Measurements } \\
\text { on periapical } \\
\text { radiographs }\end{array}$ & $\begin{array}{l}\text { Deviation from } \\
\text { "gold standard" } \\
\text { lines projected } \\
\text { by specialized } \\
\text { software }\end{array}$ & $\begin{array}{l}\text { The mean coronal deviation was } \\
0.4-0.6 \mathrm{~mm} \text { for the 3D surgical } \\
\text { guide method, } 0.4-1.0 \mathrm{~mm} \text { for the } \\
\text { wire guide, and } 1.4-3.6 \mathrm{~mm} \text { for } \\
\text { the no-guide method. } \\
\text { The mean apical deviation was } \\
0.4-2.0 \mathrm{~mm} \text { for the 3D surgical } \\
\text { guide, } 1.1-5.3 \mathrm{~mm} \text { for the wire } \\
\text { guide, and } 3.5-10.5 \mathrm{~mm} \text { for the } \\
\text { no-guide method. All the } \\
\text { mini-implants were inserted into } \\
\text { interradicular space. }\end{array}$ \\
\hline $\begin{array}{l}\text { Rashid et al., } \\
2021 \text { [35] }\end{array}$ & $\begin{array}{l}\text { Randomized } \\
\text { split-mouth } \\
\text { clinical trial }\end{array}$ & $\begin{array}{l}25 \text { implants } \\
\text { inserted with } \\
\text { the use of a 3D } \\
\text { surgical guide }\end{array}$ & $\begin{array}{l}25 \text { implants } \\
\text { inserted } \\
\text { without any } \\
\text { guide }\end{array}$ & $\begin{array}{l}\text { Measurements } \\
\text { on CBCT scans }\end{array}$ & $\begin{array}{l}\text { Deviation from } \\
\text { "gold standard" } \\
\text { lines projected } \\
\text { by specialized } \\
\text { software }\end{array}$ & $\begin{array}{l}\text { The mean values for apical } \\
\text { deviation were } 0.69 \pm 0.02 \mathrm{~mm} \text { for } \\
\text { guided screws and } 1.44 \pm 0.10 \text { for } \\
\text { hand-drilled screws, and } \\
0.60 \pm 0.03 \text { and } 2.47 \pm 0.27 \text { for } \\
\text { coronal deviation, respectively. } \\
\text { The mean mesiodistal angle was } \\
2.53 \pm 0.10 \text { for guided implants } \\
\text { and } 11.67 \pm 0.75 \text { for hand-drilled } \\
\text { group. The mean bucco-lingual } \\
\text { angle was } 0.18 \pm 0.09 \text { and } \\
10.25 \pm 0.91 \text {, respectively. All the } \\
\text { mini-implants were inserted into } \\
\text { interradicular space. }\end{array}$ \\
\hline $\begin{array}{l}\text { Dasomi Kim, } \\
2019 \text { [36] }\end{array}$ & $\begin{array}{l}\text { Randomized } \\
\text { clinical trial }\end{array}$ & $\begin{array}{l}45 \text { implants } \\
\text { inserted with } \\
\text { the use of a 3D } \\
\text { surgical guide }\end{array}$ & $\begin{array}{l}47 \text { implants } \\
\text { inserted } \\
\text { manually } \\
\text { without any } \\
\text { guide }\end{array}$ & $\begin{array}{c}\text { Measurements } \\
\text { on periapical } \\
\text { radiographs, } \\
\text { CBCT, } \\
\text { insertion } \\
\text { torque and } \\
\text { Periotest }\end{array}$ & $\begin{array}{l}\text { Percentage of } \\
\text { success rate, } \\
\text { root contact, } \\
\text { insertion } \\
\text { torque and } \\
\text { Periotest }\end{array}$ & $\begin{array}{l}\text { In the manual insertion group the } \\
\text { success rate was } 80.9 \% \text { and for the } \\
\text { guide group it was } 88.9 \% \text {. The } \\
\text { root contact rate was } 31.9 \% \text { in the } \\
\text { manual group and } 0.4 \% \text { in the } \\
\text { surgical guide group. The } \\
\text { insertion torque was } 6.37 \pm 2.64 \\
\text { Ncm in the manual group and } \\
6.54 \pm 2.90 \text { Ncm in the guide } \\
\text { group, and the Periotest value } \\
\text { was } 0.19 \pm 2.86 \text { in the guide group } \\
\text { and } 1.58 \pm 2.13 \text { in the manual } \\
\text { group. All the miniimplants were } \\
\text { inserted into interradicular space. }\end{array}$ \\
\hline $\begin{array}{c}\text { Mi-Ju Bae, } 2013 \\
\text { [37] }\end{array}$ & $\begin{array}{c}\text { Nonradmized } \\
\text { clinical } \\
\text { experimental } \\
\text { study }\end{array}$ & $\begin{array}{l}25 \text { implants } \\
\text { inserted with } \\
\text { the use of a 3D } \\
\text { surgical guide }\end{array}$ & $\begin{array}{l}20 \text { implants } \\
\text { inserted using } \\
\text { a wire guide } \\
\text { and periapical } \\
\text { radiographs }\end{array}$ & $\begin{array}{l}\text { Measurements } \\
\text { on CBCT scans }\end{array}$ & $\begin{array}{l}\text { Deviation from } \\
\text { "gold standard" } \\
\text { lines projected } \\
\text { by specialized } \\
\text { software }\end{array}$ & $\begin{array}{c}\text { Median long-axis angular } \\
\text { deviations were } 3.14^{\circ} \text { (range, } \\
1.02^{\circ}-10.9^{\circ} \text { ) for the surgical guide } \\
\text { group and } 9.57^{\circ} \text { (range, } \\
3.15^{\circ}-35.60^{\circ} \text { ) for the control } \\
\text { group. The mean apical deviation } \\
0.73 \text { was for the surgical group } \\
\text { and } 1.28 \text { for control group. The } \\
\text { mean coronal deviation was } 0.73 \\
\text { for the surgical group and } 1.56 \text { for } \\
\text { the control group. All the } \\
\text { mini-implants were inserted into } \\
\text { interradicular space. }\end{array}$ \\
\hline
\end{tabular}


Table 1. Cont

\begin{tabular}{|c|c|c|c|c|c|c|c|}
\hline $\begin{array}{c}\text { Author and } \\
\text { Year }\end{array}$ & $\begin{array}{l}\text { Type of } \\
\text { Article }\end{array}$ & $\begin{array}{l}\text { Material or } \\
\text { Subjects }\end{array}$ & $\begin{array}{l}\text { Control } \\
\text { Sample or } \\
\text { Group }\end{array}$ & Method & $\begin{array}{l}\text { Outcome } \\
\text { Measured }\end{array}$ & \multicolumn{2}{|c|}{ Results } \\
\hline $\begin{array}{l}\text { Lingling Qiu } \\
\text { et al., } 2012 \text { [38] }\end{array}$ & $\begin{array}{l}\text { Nonradmized } \\
\text { clinical } \\
\text { experimental } \\
\text { study }\end{array}$ & $\begin{array}{l}20 \text { implants } \\
\text { inserted with } \\
\text { the use of a 3D } \\
\text { surgical guide }\end{array}$ & $\begin{array}{l}10 \text { implants } \\
\text { inserted } \\
\text { manually } \\
\text { without any } \\
\text { guide }\end{array}$ & $\begin{array}{l}\text { Measurements } \\
\text { on CBCT scans }\end{array}$ & $\begin{array}{l}\text { Deviation from } \\
\text { "gold standard" } \\
\text { lines projected } \\
\text { by specialized } \\
\text { software }\end{array}$ & $\begin{array}{c}\text { Surgical } \\
\text { Guided } \\
\text { screws } \\
\text { The mean } \\
\text { apical } \\
\text { deviation was } \\
0.28 \pm 0.23 \mathrm{~mm} \\
\text { and } \\
0.33 \pm 0.25 \mathrm{~mm} \\
\text { in mesiodistal } \\
\text { and apical } \\
\text { directions. The } \\
\text { mean coronal } \\
\text { deviation was } \\
0.15 \pm 0.09 \mathrm{~mm} \\
\text { and } \\
0.19 \pm 0.19 \mathrm{~mm} \\
\text { in mesiodistal } \\
\text { and apical } \\
\text { direction. } \\
\text { The angular } \\
\text { deviations } \\
\text { were } \\
1.47^{\circ} \pm 0.56 \\
\text { and } \\
2.13^{\circ} \pm 1.48 \\
\text { respectively. } \\
\text { All the } \\
\text { mini-implants } \\
\text { were inserted } \\
\text { into } \\
\text { interradicular } \\
\text { space. }\end{array}$ & 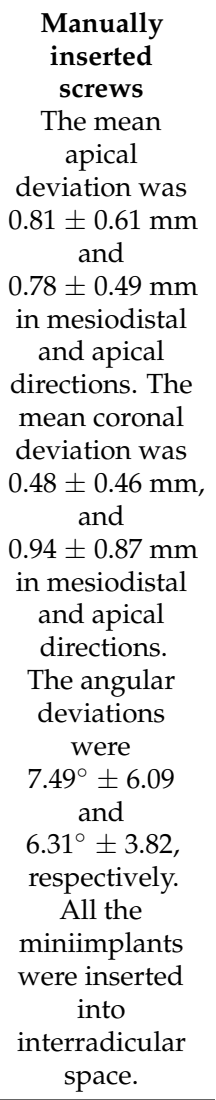 \\
\hline $\begin{array}{l}\text { Möhlhenrich } \\
\text { et al., } 2019 \text { [39] }\end{array}$ & $\begin{array}{l}\text { Nonradmized } \\
\text { clinical } \\
\text { experimental } \\
\text { study }\end{array}$ & $\begin{array}{l}20 \text { implants } \\
\text { inserted with } \\
\text { the use of a 3D } \\
\text { tooth-borne } \\
\text { surgical guide }\end{array}$ & $\begin{array}{l}20 \text { implants } \\
\text { inserted with } \\
\text { the use of a 3D } \\
\text { mucosa-borne } \\
\text { surgical guide }\end{array}$ & $\begin{array}{l}\text { Measurements } \\
\text { on } \\
\text { cephalograms, } \\
\text { plaster models } \\
\text { and intraoral } \\
\text { scans }\end{array}$ & $\begin{array}{l}\text { Deviation from } \\
\text { "gold standard" } \\
\text { lines projected } \\
\text { by specialized } \\
\text { software }\end{array}$ & $\begin{array}{r}\text { Statistical diffe } \\
\text { tooth-borne an } \\
\text { guides were de } \\
\text { deviations: } 0.88 \\
1.65 \mathrm{~mm} \pm 1 . \\
\text { angular deviati } \\
\text { versus } 6.46^{\circ} \pm \\
\text { were inserted in } \\
\mathrm{sp}\end{array}$ & $\begin{array}{l}\text { ences between } \\
\text { mucosa-borne } \\
\text { cted for lateral } \\
\mathrm{m} \pm 0.46 \text { versus } \\
3 \text { and sagittal } \\
\text { as: } 3.67^{\circ} \pm 2.25 \\
5.5 \text {. All the MI } \\
\text { o interradicular } \\
\text { ce. }\end{array}$ \\
\hline $\begin{array}{l}\text { Möhlhenrich } \\
\text { et al., } 2020 \text { [40] }\end{array}$ & $\begin{array}{l}\text { Nonradmized } \\
\text { clinical } \\
\text { experimental } \\
\text { study }\end{array}$ & $\begin{array}{l}20 \text { implants } \\
\text { inserted with } \\
\text { the use of a 3D } \\
\text { tooth-borne } \\
\text { surgical guide }\end{array}$ & $\begin{array}{l}20 \text { implants } \\
\text { inserted with } \\
\text { the use of 3D a } \\
\text { mucosa-borne } \\
\text { surgical guide }\end{array}$ & $\begin{array}{l}\text { Measurements } \\
\text { on } \\
\text { cephalograms, } \\
\text { CBCT, plaster } \\
\text { models and } \\
\text { intraoral scans }\end{array}$ & $\begin{array}{l}\text { Deviation from } \\
\text { "gold standard" } \\
\text { lines projected } \\
\text { by specialized } \\
\text { software } \\
\text { separately on } \\
\text { cephalogram } \\
\text { and CBCT }\end{array}$ & $\begin{array}{r}\text { Significant differ } \\
\text { and T1 were on } \\
\text { of lateral devi } \\
\text { tooth-born } \\
4.7 \pm 2.3 \mathrm{~mm}, \mathrm{~T} \\
\text { and linear sagitt } \\
\text { the mucosa-b } \\
3.1 \pm 3.5 \mathrm{~mm}, \mathrm{~T} \\
\text { All the mini- } \\
\text { inserted i }\end{array}$ & $\begin{array}{l}\text { nces between T0 } \\
\text { noted in terms } \\
\text { tion using the } \\
\text { guide (T0: } \\
: 3.0 \pm 2.3 \mathrm{~mm} \text {; } \\
\text { deviation using } \\
\text { rne guide (T0: } \\
: 2.3 \pm 3.2 \mathrm{~mm}) \text {. } \\
\text { nplants were } \\
\text { to palate. }\end{array}$ \\
\hline $\begin{array}{l}\text { Kniha et al., } \\
2020 \text { [41] }\end{array}$ & $\begin{array}{l}\text { Nonradmized } \\
\text { clinical } \\
\text { experimental } \\
\text { study }\end{array}$ & $\begin{array}{l}20 \text { implants } \\
\text { inserted with } \\
\text { the use of a 3D } \\
\text { tooth-borne } \\
\text { surgical guide }\end{array}$ & $\begin{array}{l}20 \text { implants } \\
\text { inserted with } \\
\text { the use of a 3D } \\
\text { mucosa-borne } \\
\text { surgical guide }\end{array}$ & $\begin{array}{l}\text { Measurements } \\
\text { on CBCT scans }\end{array}$ & $\begin{array}{l}\text { Deviation from } \\
\text { "gold standard" } \\
\text { lines projected } \\
\text { by specialized } \\
\text { software }\end{array}$ & $\begin{array}{r}\text { The only statisti } \\
\text { different varial } \\
\text { axis angulation } \\
\text { guides it was } \\
\text { mucosa-born } \\
6.22^{\circ} \pm 4 . \\
\text { mini-implants } \\
\text { interradic }\end{array}$ & $\begin{array}{l}\text { ally significantly } \\
\text { le was implant } \\
\text { In tooth-borne } \\
81^{\circ} \pm 2.69 \text {. In } \\
\text { guides it was } \\
6 \text {. All the } \\
\text { ere inserted into } \\
\text { lar space. }\end{array}$ \\
\hline
\end{tabular}


Table 1. Cont.

\begin{tabular}{|c|c|c|c|c|c|c|}
\hline $\begin{array}{l}\text { Author and } \\
\text { Year }\end{array}$ & $\begin{array}{l}\text { Type of } \\
\text { Article }\end{array}$ & $\begin{array}{l}\text { Material or } \\
\text { Subjects }\end{array}$ & $\begin{array}{l}\text { Control } \\
\text { Sample or } \\
\text { Group }\end{array}$ & Method & $\begin{array}{l}\text { Outcome } \\
\text { Measured }\end{array}$ & Results \\
\hline $\begin{array}{c}\text { Federica Altieri } \\
\text { and Michele } \\
\text { Cassetta, } 2020 \\
{[42]}\end{array}$ & $\begin{array}{l}\text { Randomized } \\
\text { clinical trial }\end{array}$ & $\begin{array}{l}18 \text { subjects } \\
\text { with computer- } \\
\text { aided designed } \\
\text { skeletal RME } \\
\text { appliance }\end{array}$ & $\begin{array}{c}18 \text { subjects } \\
\text { with classic } \\
\text { hyrax } \\
\text { appliance }\end{array}$ & $\begin{array}{c}\text { Pain scales and } \\
\text { shortened Oral } \\
\text { Health Impact } \\
\text { Profile } \\
\text { (OHIP-14) } \\
\text { questionnaire }\end{array}$ & $\begin{array}{l}\text { Level of pain } \\
\text { and quality of } \\
\text { life for } 14 \text { days } \\
\text { after insertion }\end{array}$ & $\begin{array}{l}\text { The only differences were noted } \\
\text { on the day of screw activation. } \\
\text { Patients with a computer-guided } \\
\text { skeletal RME appliance felt less } \\
\text { comfortable. All the } \\
\text { mini-implants were inserted into } \\
\text { interradicular space. }\end{array}$ \\
\hline
\end{tabular}

\subsection{Quality Assessment}

The results of quality assessment are presented in Table 2.

Table 2. Mixed Methods Appraisal Tool (MMAT), version 2018 for quantitative randomized and nonrandomized studies.

\begin{tabular}{|c|c|c|c|c|c|c|c|c|c|c|}
\hline $\begin{array}{l}\text { Category } \\
\text { of Study } \\
\text { Designs }\end{array}$ & $\begin{array}{l}\text { Methodological } \\
\text { Quality Criteria }\end{array}$ & $\begin{array}{l}\text { Suzuki } \\
\text { and } \\
\text { Suzuki, } \\
2007\end{array}$ & $\begin{array}{l}\text { Rashid } \\
\text { et al., } \\
2021\end{array}$ & $\begin{array}{l}\text { Dasomi } \\
\text { Kim, } \\
2019\end{array}$ & $\begin{array}{c}\text { Mi-Ju } \\
\text { Bae, } \\
2013\end{array}$ & $\begin{array}{l}\text { Lingling } \\
\text { Qiu et al., } \\
2012\end{array}$ & $\begin{array}{l}\text { Möhlhenrich } \\
\text { et al., } 2019\end{array}$ & $\begin{array}{l}\text { Möhlhenrich } \\
\text { et al., } 2020\end{array}$ & $\begin{array}{l}\text { Kniha } \\
\text { et al., } 2020\end{array}$ & $\begin{array}{l}\text { Federica } \\
\text { Altieri and } \\
\text { Michele } \\
\text { Cassetta, } \\
2020\end{array}$ \\
\hline \multirow{2}{*}{$\begin{array}{l}\text { Screening } \\
\text { questions }\end{array}$} & $\begin{array}{l}\text { S1. Are there clear } \\
\text { research questions? }\end{array}$ & Yes & Yes & Yes & Yes & Yes & Yes & Yes & Yes & Yes \\
\hline & $\begin{array}{l}\text { S2. Do the collected } \\
\text { data allow to address } \\
\text { the research questions? }\end{array}$ & Yes & Yes & Yes & Yes & Yes & Yes & Yes & Yes & Yes \\
\hline \multirow{5}{*}{$\begin{array}{l}\text { Quantitative } \\
\text { randomized } \\
\text { controlled } \\
\text { trials }\end{array}$} & $\begin{array}{l}\text { 1.1. Is randomization } \\
\text { appropriately } \\
\text { performed? }\end{array}$ & $\mathrm{N} / \mathrm{A}$ & Yes & Yes & $\mathrm{N} / \mathrm{A}$ & $\mathrm{N} / \mathrm{A}$ & $\mathrm{N} / \mathrm{A}$ & $\mathrm{N} / \mathrm{A}$ & $\mathrm{N} / \mathrm{A}$ & Yes \\
\hline & $\begin{array}{l}\text { 1.2. Are the groups } \\
\text { comparable at } \\
\text { baseline? }\end{array}$ & $\mathrm{N} / \mathrm{A}$ & Yes & Yes & $\mathrm{N} / \mathrm{A}$ & $\mathrm{N} / \mathrm{A}$ & $\mathrm{N} / \mathrm{A}$ & $\mathrm{N} / \mathrm{A}$ & $\mathrm{N} / \mathrm{A}$ & Yes \\
\hline & $\begin{array}{l}\text { 1.3. Are there complete } \\
\text { outcome data? }\end{array}$ & $\mathrm{N} / \mathrm{A}$ & Yes & Yes & $\mathrm{N} / \mathrm{A}$ & $\mathrm{N} / \mathrm{A}$ & $\mathrm{N} / \mathrm{A}$ & $\mathrm{N} / \mathrm{A}$ & $\mathrm{N} / \mathrm{A}$ & Yes \\
\hline & $\begin{array}{l}\text { 1.4. Are outcome } \\
\text { assessors blinded to } \\
\text { the intervention } \\
\text { provided? }\end{array}$ & $\mathrm{N} / \mathrm{A}$ & Can't tell & $\mathrm{No}^{*}$ & $\mathrm{~N} / \mathrm{A}$ & $\mathrm{N} / \mathrm{A}$ & $\mathrm{N} / \mathrm{A}$ & $\mathrm{N} / \mathrm{A}$ & $\mathrm{N} / \mathrm{A}$ & $\mathrm{No}^{*}$ \\
\hline & $\begin{array}{l}1.5 \text { Did the } \\
\text { participants adhere to } \\
\text { the assigned } \\
\text { intervention? }\end{array}$ & $\mathrm{N} / \mathrm{A}$ & Yes & Yes & $\mathrm{N} / \mathrm{A}$ & $\mathrm{N} / \mathrm{A}$ & $\mathrm{N} / \mathrm{A}$ & $\mathrm{N} / \mathrm{A}$ & $\mathrm{N} / \mathrm{A}$ & Yes \\
\hline \multirow{5}{*}{$\begin{array}{l}\text { Quantitative } \\
\text { nonran- } \\
\text { domized }\end{array}$} & $\begin{array}{l}\text { 2.1. Are the } \\
\text { participants } \\
\text { representative of the } \\
\text { target population? }\end{array}$ & Yes & $\mathrm{N} / \mathrm{A}$ & $\mathrm{N} / \mathrm{A}$ & Can't tell & No & Yes & Yes & Yes & $\mathrm{N} / \mathrm{A}$ \\
\hline & $\begin{array}{l}\text { 2.2. Are measurements } \\
\text { appropriate regarding } \\
\text { both the outcome and } \\
\text { intervention (or } \\
\text { exposure)? }\end{array}$ & Yes & $\mathrm{N} / \mathrm{A}$ & $\mathrm{N} / \mathrm{A}$ & Can't tell & Yes & Yes & Yes & Yes & $\mathrm{N} / \mathrm{A}$ \\
\hline & $\begin{array}{l}\text { 2.3. Are there complete } \\
\text { outcome data? }\end{array}$ & Yes & $\mathrm{N} / \mathrm{A}$ & $\mathrm{N} / \mathrm{A}$ & Yes & Yes & Yes & Yes & Yes & $\mathrm{N} / \mathrm{A}$ \\
\hline & $\begin{array}{l}\text { 2.4. Are the } \\
\text { confounders } \\
\text { accounted for in the } \\
\text { design and analysis? }\end{array}$ & Yes & $\mathrm{N} / \mathrm{A}$ & $\mathrm{N} / \mathrm{A}$ & $\mathrm{No}^{*}$ & $\mathrm{No}^{*}$ & $\mathrm{No}^{*}$ & $\mathrm{No}^{*}$ & $\mathrm{No}^{*}$ & $\mathrm{~N} / \mathrm{A}$ \\
\hline & $\begin{array}{l}\text { 2.5. During the study } \\
\text { period, is the } \\
\text { intervention } \\
\text { administered (or } \\
\text { exposure occurred) as } \\
\text { intended? }\end{array}$ & Yes & $\mathrm{N} / \mathrm{A}$ & $\mathrm{N} / \mathrm{A}$ & Yes & Yes & Yes & Yes & Yes & $\mathrm{N} / \mathrm{A}$ \\
\hline
\end{tabular}

*_additionally, no error study is performed, when possible. 
The overall quality of the evidence is good or average; none of the included studies were characterized by a low quality. Error study and power study were not performed for all of the studies. Most of the studies did not address the limitations that might arise from the design of the given study.

\subsection{Meta-Analysis}

The following meta-analysis was performed in order to compare the range of apical deviation (in $\mathrm{mm}$ ) of miniscrews inserted using different methods. If this value was not provided, the study was excluded from a meta-analysis. Due to the large diversity of the included studies, as many as 3 comparisons were made:

(a) Accuracy of insertion of mini-implants using a 3D surgical guide to these inserted manually (no-guide). Three studies were included in the meta-analysis. The total sample size of all included studies was 220 implants.

(b) Accuracy of insertion of mini-implants using a 3D surgical guide in comparison to those inserted using a less-advanced method (manually and wire guides combined). There were four included studies in meta-analysis. The total sample size of all included studies was 285 implants.

(c) Accuracy of insertion of mini-implants using a tooth-borne 3D surgical guide to these inserted using mucosa-borne ones. Three studies were included in the meta-analysis. The total sample size of all included studies was 120 implants.

Data from all of the studies included in first and second comparison concern miniimplants inserted into the interradicular space. However, data from all of the studies included in the first and second comparison concern mini-implants inserted into the palate. The extracted data that were used to perform meta-analysis are presented in Tables 3-5.

Table 3. Differences in apical deviation to the "gold standard line" of the mini-implants inserted with the use of 3D surgical guide and the mini-implants inserted manually.

\begin{tabular}{|c|c|c|c|c|}
\hline \multirow{2}{*}{ Author and Year } & \multicolumn{2}{|c|}{$\begin{array}{c}\text { Deviation in the Group with the Use of } \\
\text { Surgical Guide }\end{array}$} & \multicolumn{2}{|c|}{$\begin{array}{c}\text { Deviation in the Group Where Implant Was } \\
\text { Inserted Manually }\end{array}$} \\
\hline & No. of Implants & Values in mm & No. of Implants & Values in $\mathbf{m m}$ \\
\hline Suzuki and Suzuki, 2007 [34] & 120 & $2.0 \pm 0.4 \mathrm{~mm}$ & 20 & $10.5 \pm 3.5 \mathrm{~mm}$ \\
\hline Rashid et al., 2021 [35] & 25 & $0.69 \pm 0.02 \mathrm{~mm}$ & 25 & $1.44 \pm 0.10 \mathrm{~mm}$ \\
\hline Lingling Qiu et al., 2012 [38] & 20 & $\begin{array}{c}0.28 \pm 0.23 \mathrm{~mm} \\
(\text { mesiodistal }) \\
0.33 \pm 0.25 \mathrm{~mm} \\
\quad(\text { vertical })\end{array}$ & 10 & $\begin{array}{c}0.81 \pm 0.61 \mathrm{~mm} \\
(\text { mesiodistal }) \\
0.78 \pm 0.49 \mathrm{~mm} \\
\quad \text { (vertical) }\end{array}$ \\
\hline
\end{tabular}

Table 4. Differences in apical deviation to the "gold standard line" of mini-implants inserted with the use of 3D surgical guides and mini-implants inserted manually or with a wire guide.

\begin{tabular}{|c|c|c|c|c|}
\hline \multirow{2}{*}{ Author and Year } & \multicolumn{2}{|c|}{$\begin{array}{l}\text { Deviation in the Group with the Use of } \\
\text { Surgical Guide }\end{array}$} & \multicolumn{2}{|c|}{$\begin{array}{c}\text { Deviation in the Group Where Implant Was Inserted } \\
\text { Manually or with Wire Guide }\end{array}$} \\
\hline & No. of Implants & $\begin{array}{l}\text { Values in } \mathrm{mm} / \text { Root } \\
\text { Contact Rate }\end{array}$ & No. of Implants & $\begin{array}{l}\text { Values in } \mathrm{mm} / \text { Root } \\
\text { Contact Rate }\end{array}$ \\
\hline Suzuki and Suzuki, 2007 [34] & 120 & $2.0 \pm 0.4 \mathrm{~mm}$ & 20 & $10.5 \pm 3.5 \mathrm{~mm}$ \\
\hline Suzuki and Suzuki, 2007 [34] & 120 & $2.0 \pm 0.4 \mathrm{~mm}$ & 20 & $5.3 \pm 1.1 \mathrm{~mm}$ \\
\hline Rashid et al., 2021 [35] & 25 & $0.69 \pm 0.02 \mathrm{~mm}$ & 25 & $1.44 \pm 0.10 \mathrm{~mm}$ \\
\hline Mi-Ju Bae, 2013 [37] & 25 & $0.73 \mathrm{~mm}(0.24-2.07)$ & 20 & $1.28 \mathrm{~mm}(0.26-3.81)$ \\
\hline Lingling Qiu et al., 2012 [38] & 20 & $\begin{array}{c}0.28 \pm 0.23 \mathrm{~mm} \\
(\text { mesiodistal) } \\
0.33 \pm 0.25 \mathrm{~mm} \\
\text { (vertical) }\end{array}$ & 10 & $\begin{array}{c}0.81 \pm 0.61 \mathrm{~mm} \\
(\text { mesiodistal) } \\
0.78 \pm 0.49 \mathrm{~mm} \\
\text { (vertical) }\end{array}$ \\
\hline
\end{tabular}


Table 5. Differences in apical vertical deviation to the "gold standard line" of mini-implants inserted with the use of a 3D tooth-borne surgical guide and MIs inserted with the use of a mucosa-borne surgical guide.

\begin{tabular}{ccccc}
\hline \multirow{2}{*}{\begin{tabular}{c} 
Author and Year \\
\cline { 2 - 4 }
\end{tabular}} & \multicolumn{2}{c}{\begin{tabular}{c} 
Deviation in the Group with a \\
Tooth-Borne Surgical Guide \\
\cline { 2 - 5 } No. of Implants
\end{tabular}} & $\begin{array}{c}\text { Values in Linear } \\
\text { Deviation in mm }\end{array}$ & $\begin{array}{c}\text { Deviation in the Group with a Mucosa-Borne } \\
\text { Surgical Guide }\end{array}$ \\
\hline Möhlhenrich et al. 2019 [39] & 20 & $0.88 \pm 0.46 \mathrm{~mm}$ & $\begin{array}{c}\text { Values in Linear } \\
\text { Deviation in mm }\end{array}$ \\
\hline Möhlhenrich et al. 2020 [40] & 20 & $1.7 \pm 1.2 \mathrm{~mm}$ & 20 & $1.65 \pm 1.03 \mathrm{~mm}$ \\
\hline Kniha et al. 2020 [41] & 20 & $0.10 \pm 0.46 \mathrm{~mm}$ & 20 & $1.6 \pm 1.5 \mathrm{~mm}$ \\
\hline
\end{tabular}

\section{(a) The first comparison}

Four studies were included in the meta-analysis. The results are shown in Figure 2. A positive value for the Standardized mean difference indicates a greater efficacy of the surgical guide, whereas a negative value indicates manual insertion.

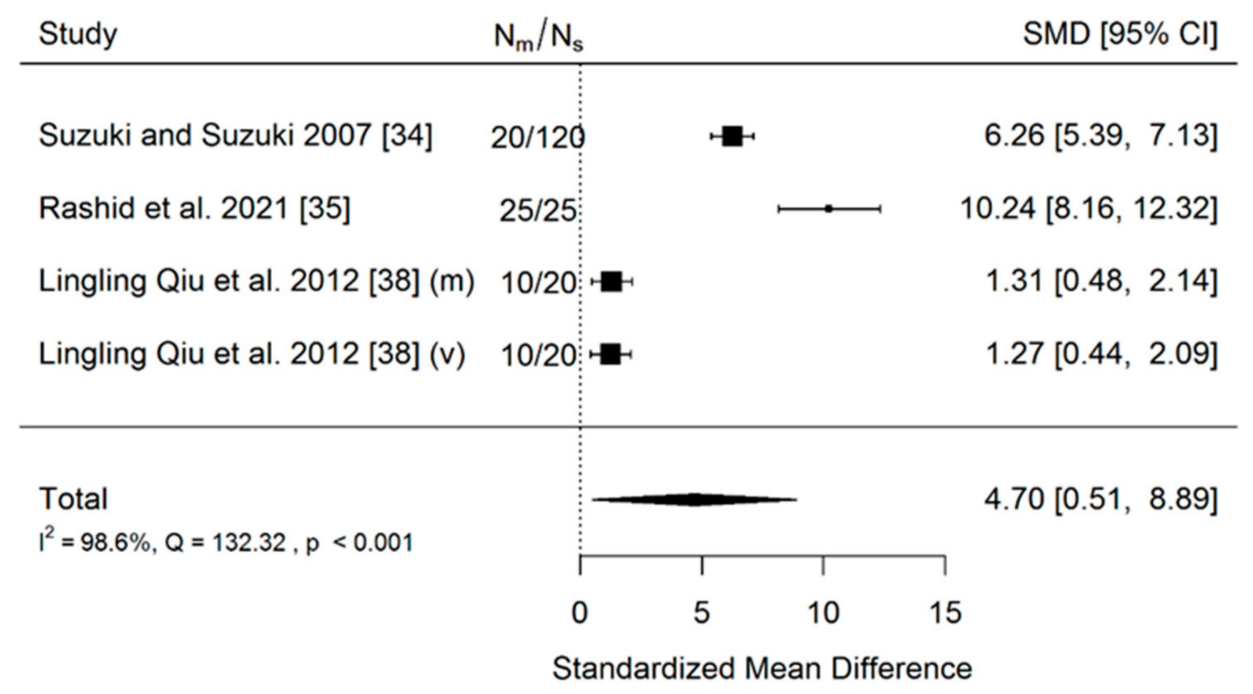

Figure 2. Forest plot of 4 studies in the first comparison performed. $\mathrm{N}_{\mathrm{m}}$-number of mini-implants inserted manually; $\mathrm{N}_{\mathrm{s}}$-number of mini-implants inserted with the use of 3D surgical guide.

Positive values of SMD indicate a greater efficacy of the surgical guide, negative indicates manual insertion. Nm represents the number of implants inserted with 3D surgical guide and Ns represents the number of implants inserted manually. The usage of a surgical guide has great significance $(p=0.028)$ on the positive effect size. Study results are found to be inconsistent-heterogeneity is significant $(p<0.001)$, more than $98 \%$ of the variability comes from heterogeneity. All points on the funnel plot (Figure 3) are outside the funnel due to a high heterogeneity, the asymmetry also suggests a publication bias.

\section{(b) The second comparison}

There were six results found from the four studies included in the meta-analysis. Mi-Ju Bae, 2013 [37] reported ranges instead of standard deviations, so the range rule [33] was used to estimate standard deviations for this study. The results are shown in Figure 4. A positive value of Standardized mean difference indicates a greater efficacy of surgical guide, negative indicates manual insertion. 


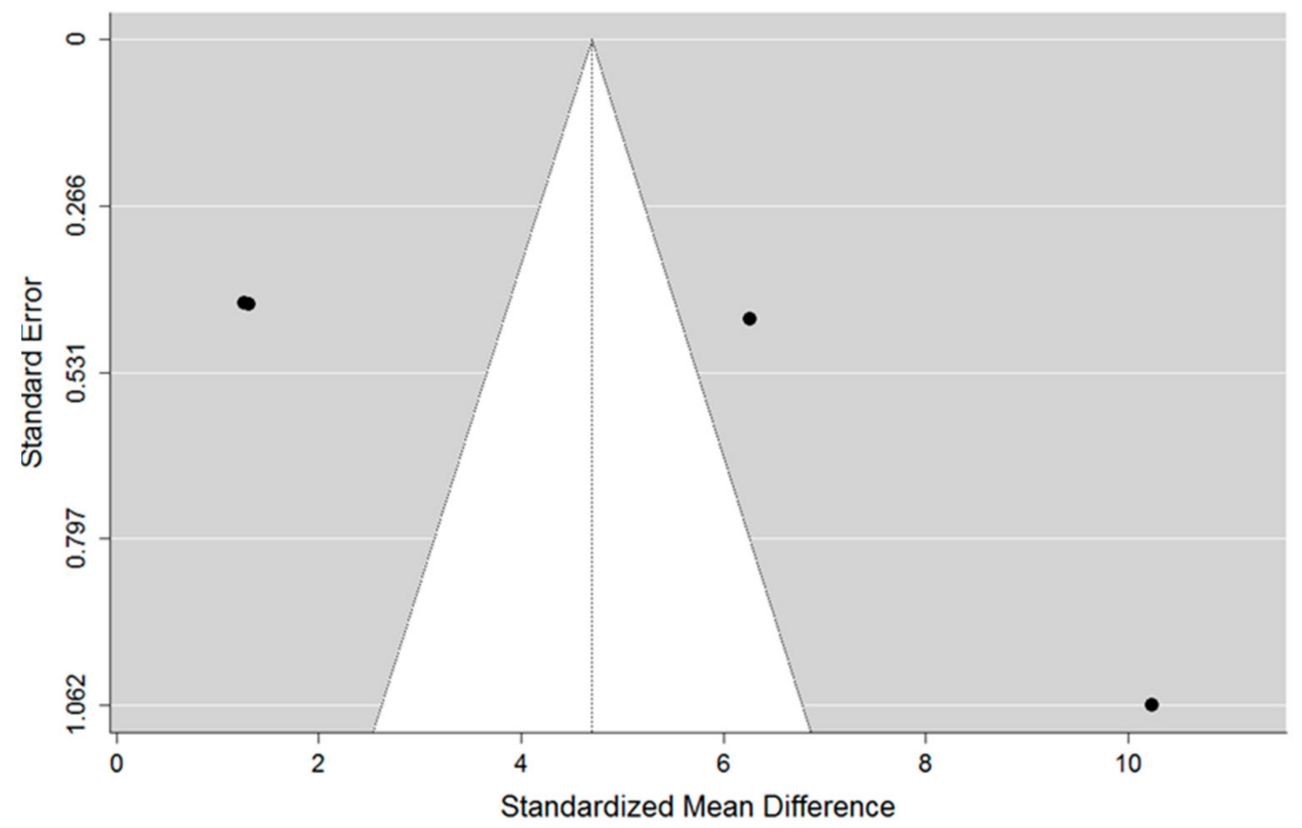

Figure 3. Funnel plot of 4 studies suggests publication bias.

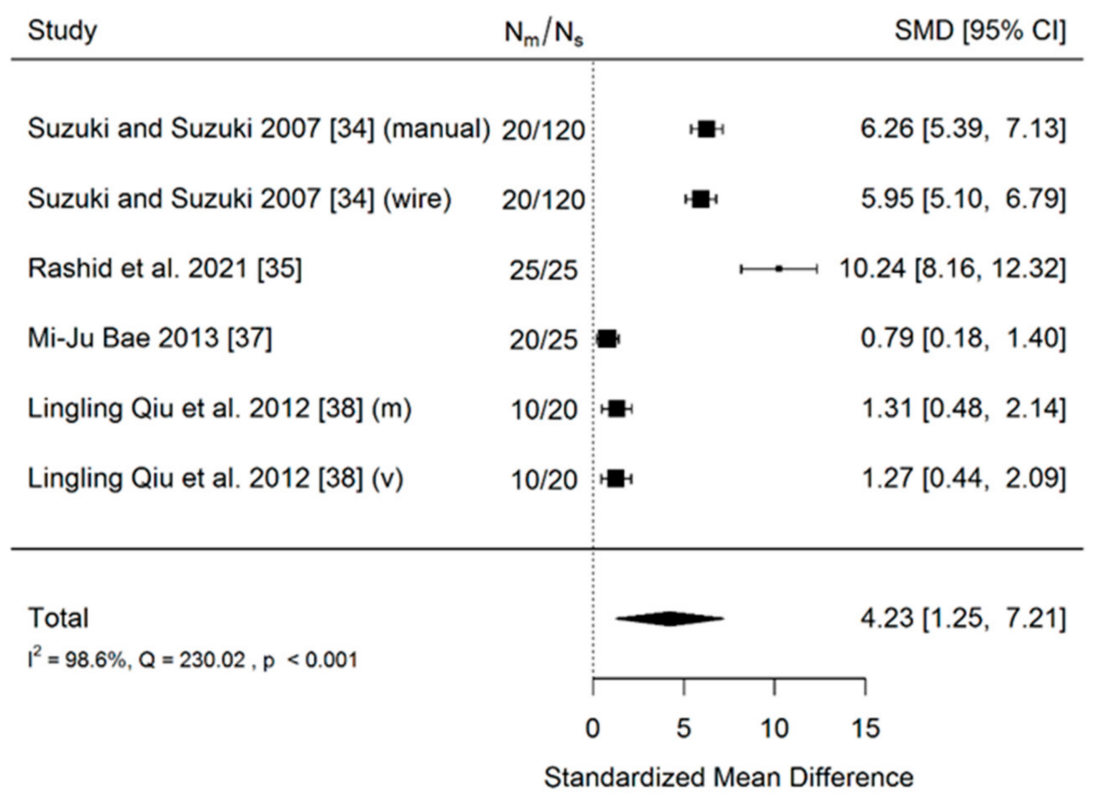

Figure 4. Forest plot of 4 studies of the second comparison. $\mathrm{N}_{\mathrm{m}}$-number of mini-implants inserted manually or with wire guide; $\mathrm{N}_{\mathrm{s}}$-number of mini-implants inserted with the use of 3D surgical guide.

A positive value of SMD indicates a greater efficacy of surgical guides, negative-of manual insertion. Nm-number MI inserted with 3D surgical guide and Ns number of MI inserted with a wire guide or manually. The usage of surgical guides has very a large significant $(p=0.005)$ positive effect size. Study results are found to be inconsistentheterogeneity is significant $(p<0.001)$, more than $98 \%$ of the variability derives from heterogeneity. All points on the funnel plot (Figure 5) are outside the funnel due to a high heterogeneity, the asymmetry also suggests a publication bias. 


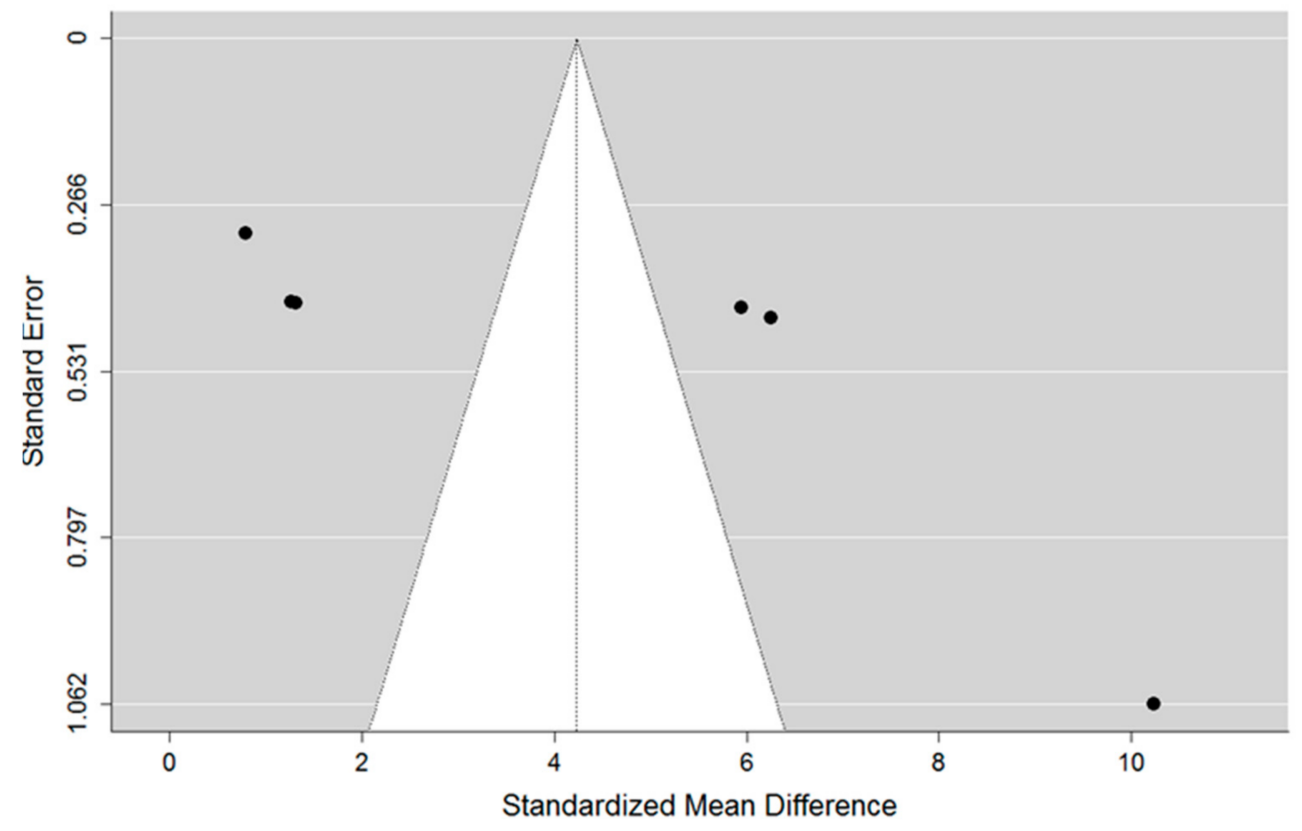

Figure 5. Funnel plot of 4 studies suggests publication bias.

\section{(c) The third comparison}

There were 3 included studies in the meta-analysis. The results are shown on Figure 6. Positive value of Standardized mean difference indicates a greater efficacy of a tooth-borne surgical guide, negative — of a gingiva-borne surgical guide.

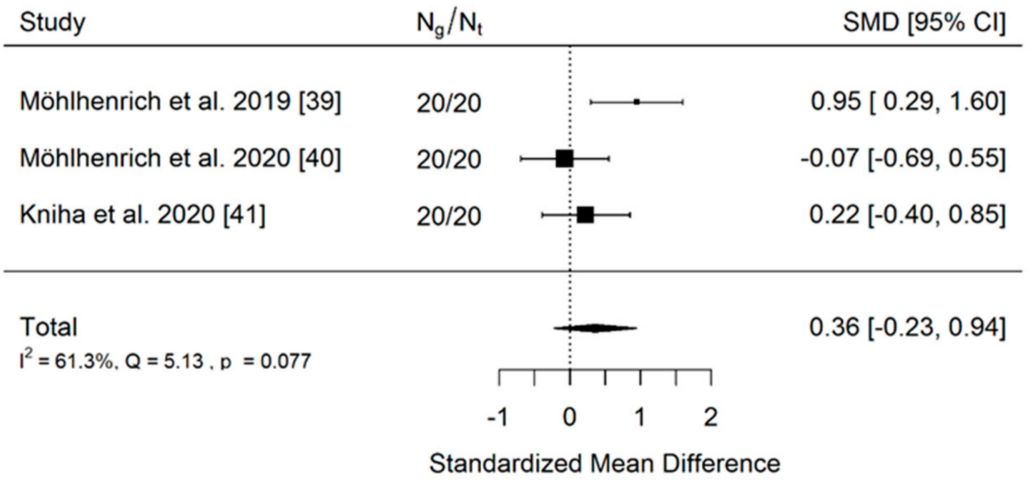

Figure 6. Forest plot of 3 studies of the third comparison performed. $\mathrm{N}_{\mathrm{g}}$-number of mini-implants inserted with gingiva-borne (mucosa-borne) surgical guide; $\mathrm{N}_{\mathrm{t}}$-number of mini-implants inserted with tooth-borne surgical guide.

Positive value of SMD indicates a greater efficacy of the tooth-borne surgical guide, negative - of a gingiva-borne surgical guide. $\mathrm{Ng}$ and $\mathrm{Nt}-$ number of gingiva-borne and tooth-borne surgical guides. The usage of tooth-borne surgical guide vs. gingiva-borne surgical guide has an insignificant $(p=0.231)$ positive effect size. Study results are consistentheterogeneity is insignificant $(p=0.077)$, around $61 \%$ of the variability derives from heterogeneity. The funnel plot (Figure 7) does not reveal a publication bias. 


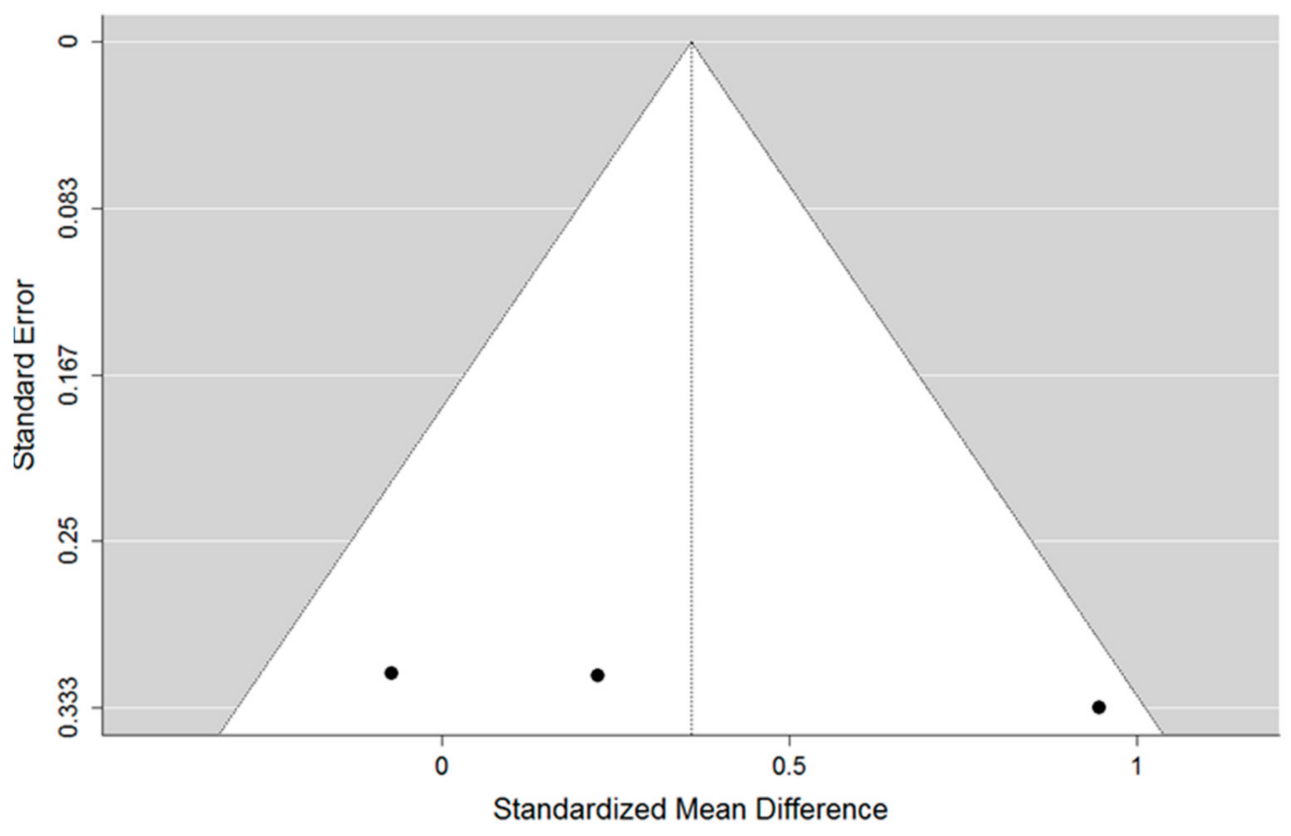

Figure 7. Funnel plot of the third comparison did not reveal any publication bias.

\section{Discussion}

This systematic review aimed to find scientific evidence justifying the use of 3D surgical guides for mini-implant insertion in everyday orthodontic practice. The number of articles included may appear small given the overall literature on guided mini-implant insertion [34-42]. However, most papers are based on a very limited numbers of cases and lack appropriate control groups to adequately assess the potential benefits of using 3D surgical guides [18-24,43-46]. It should be taken into account that guide fabrication makes guided mini-implant procedures more expensive and more time-consuming than direct manual insertion. However, as of yet no studies have been published regarding the cost-effectiveness of the 3D guided procedure. The authors intended to find evidence both on precision and efficacy. Finally, clinical efficacy, described in the form of an assessment of the comfort of solutions based on micro-implants, was only described in one paper.

Among the different scales for the quality assessment of scientific papers, the authors selected the MMAT, intending to unify a quality assessment of all the studies included in this systematic review and to avoid the over-division of a quality assessment by using type-specific scales.

The overall quality of the studies according to the scale applied seem to be a consequence of the strict inclusion criteria applied in the present study. One of the criteria of quality assessment refers to the participants' adherence to the assigned intervention. Since the intervention in the studies included [34-42] the insertion of a screw, the studies included gained favorable scoring with regard to the criterium mentioned. Similarly, the score is found to be positive in terms of administering the intervention or the occurrence of exposure during the study period, as intended.

The apical deviation in $\mathrm{mm}$ was selected as a variable for a meta-analysis because of its high clinical relevance (comparing to angular or coronal deviation) [47]. The clinician primarily wants to avoid root contact or damage to important anatomical structures that are situated at a deeper level $[47,48]$. The publication bias and the heterogeneity may be explained by the constant technological progress in dentistry. The oldest study included in the review is from 2007 and the newest is from 2021. It is obvious that the CAD/CAM technique has become much more advanced $( \pm 2 \mathrm{~mm}$ of accuracy in the study coming from 2007 to $\pm 0.69 \mathrm{~mm}$ from the study coming form 2021). The variables obtained in the most recent studies are definitely found to be smaller than those considered small using the IT equipment from past studies. Hence, the differences in the reported values observed on the 
funnel plot, despite clear and uniform tendencies, are noticeable on forest-diagrams. On the other hand, the third funnel plot did not reveal a publication bias (Figure 7) probably due to the fact that the research included originates from a much shorter period of time. Therefore, it should be assumed that the technological solutions used in the studies are comparable. It is also important to consider that the data included in the first two comparisons concern interradicular spaces, while the third concerns mini-implants inserted into the palate. Furthermore, one should not forget about the heterogeneity resulting from the different methods of performing the procedure (operator-bias), implant system, drilling method and analysis as to the certainty of introduction. In some cases they were objective methods (Periotest), in others a subjective analysis of the operator was followed by radiological analysis. Nevertheless, in view of the meta-analysis performed, the results of research on mini-implants inserted into the palate can be considered more reliable than the ones on mini-implants inserted into interradicular spaces. However, regardless of the year and insertion site of the studies included, using a 3D surgical guide has always had a significant positive impact on accuracy compared to other methods.

In the study by Bae et al. the median long-axis angular deviations were: $3.14^{\circ}$ (range, $1.02^{\circ}-10.9^{\circ}$ ) for the surgical guide group, and $9.57^{\circ}$ (range, $3.15^{\circ}-35.60^{\circ}$ ) for the control group. The mean apical deviation was 0.73 for the surgical group and 1.28 for control group. The mean coronal deviation was 0.73 for the surgical group and 1.56 for the control group. The fact that the authors of the study cited present a median of the angular measurements indicates a high diversity of the measurements, which may indicate a low predictability of the direction of the screw insertion, especially using a wire guide. Furthermore, other articles included in the review show that angular deviation proves to be the value with the greatest variability between studies. This confirms the necessity to ensure a control group while performing this type of research, due to the high dependence of the results on the specific operator.

Numerous studies that use CBCT to assess bone amount and quality as well as root proximity in terms of placing orthodontic mini-implants for temporary anchorage $[36,48,49]$ have been published in recent years. An assessment of the conditions at the planned surgical site is crucial. Factors considered crucial to the successful insertion of the implant include mini-implant length and diameter, the site of insertion and the patient's age [50]. An interesting practical novelty is the scientific evidence provided by Möhlhenrich et al. that an intraoral scan, taken in order to superimpose on a previously performed CBCT, is sufficient for the accurate analysis of mini-implant position [40,41]. Thus, the patient is protected from additional $\mathrm{X}$-ray radiation exposure and the intraoral scanner gains a new clinical application, leading to the more frequent use of scanners in everyday orthodontic practice [51].

Many recent studies investigate implant stability [52-54] since mini-implant loss requires new screw insertion and is associated with patient's dissatisfaction. Interestingly, mini-implants introduced through guides, primarily 3D guides, are characterized by superior biomechanical features over those introduced manually. This fact should be considered as another significant advantage in favor of guided insertion. It seems that 3D surgical guides are especially beneficial for patients with narrow interradicular spaces. Kuroda et al. stated that root proximity presents the major risk of failure while using mini-implants, due to worse biomechanical characteristic of such anchorage [55]. On the other hand, mini-implants inserted with 3D surgical guides are also characterized by higher values of removal torque. This is not surprising, given the fact that a higher removal torque is associated with better osseointegration [56]. This is consistent with the Perio test values presented in the study by Dasomi et al. [41]. It should be into consideration that not only the insertion, but also the removal of miniscrews have been associated with adverse effects such as secondary bleeding, miniscrew fracture, scars, and exostosis [4]. Future research could be directed towards the use of artificial intelligence, as it is successfully used in many branches of dentistry, for detailed surface analysis, tissue composition and CBCT images [57,58]. Possible limitations of the present study may derive from the fact 
that the studies included used different software, various materials for printing guides and different types of mini-implants. Moreover, they were performed across a period of more than 14-years, which could significantly influence the accuracy of MI systems and imaging software. Another limitation is the scarce amount of data contained in each of the meta-analyses performed, which results from the limited availability of relevant studies. In the future, it would be worth carrying out a cost-effectiveness study to determine whether economic benefits exist in fabricating 3D templates for orthodontic MI placement.

\section{Conclusions}

(1) The current literature concerning guided MI insertion consists primarily of articles presenting a low methodological level, mainly technical papers or studies carried out without a control group. High-quality clinical trials, which exclude software-bias and operator-bias in their methodological flow, are in a minority.

(2) The use of surgical guides increases mini-implant insertion accuracy and stability and reduces the failure rate of orthodontic miniscrews.

(3) Tooth-borne insertion guides, supported on the edges of teeth, ensure a higher insertion precision compared to mucosa-borne guides.

Supplementary Materials: The following are available online at https: / www.mdpi.com/article / 10.3390/coatings11121488/s1, Table S1: Prisma 2020 Checklist, Table S2: Prisma 2020 For Abstracts Checklist.

Author Contributions: Conceptualization, G.G.; methodology, M.J. and M.M.; software, M.J.; validation, J.J.-O., K.G. and L.O.; formal analysis, J.J.-O.; investigation, M.J.; resources, M.J.; data curation, M.J.; writing — original draft preparation, M.J.; writing—review and editing, J.J.-O. and G.G.; visualization, M.J. and M.M.; supervision, G.G. and L.O.; project administration, J.J.-O.; funding acquisition, K.G. and J.J.-O. All authors have read and agreed to the published version of the manuscript.

Funding: This research received no external funding.

Institutional Review Board Statement: Not applicable.

Informed Consent Statement: Not applicable.

Data Availability Statement: The data presented in this study are available upon reasonable request from the corresponding author.

Conflicts of Interest: The authors declare no conflict of interest.

$\begin{array}{ll}\text { Abbreviations } \\ \text { TAD } & \text { Temporary anchorage device } \\ \text { MI } & \text { Mini-implant } \\ \text { CBCT } & \text { Cone Beam Computed Tomography } \\ \text { MMAT } & \text { Mixed Methods Appraisal Tool }\end{array}$

\section{References}

1. Antoszewska-Smith, J.; Sarul, M.; Łyczek, J.; Konopka, T.; Kawala, B. Effectiveness of orthodontic miniscrew implants in anchorage reinforcement during en-masse retraction: A systematic review and meta-analysis. Am. J. Orthod. Dentofac. Orthop. 2017, 151, 440-455. [CrossRef] [PubMed]

2. Baumgaertel, S. Temporary skeletal anchorage devices: The case for miniscrews. Am. J. Orthod. Dentofac. Orthop. 2009, 145, 558-564. [CrossRef] [PubMed]

3. Gainsforth, B.; Higley, L. A study of orthodontic anchorage possibilities in basal bone. Am. J. Orthod. Oral Surg. 1945, 31, 406-417. [CrossRef]

4. Giudice, A.L.; Rustico, L.; Longo, M.; Oteri, G.; Papadopoulos, M.A.; Nucera, R. Complications reported with the use of orthodontic miniscrews: A systematic review. Korean J. Orthod. 2021, 51, 199-216. [CrossRef] [PubMed]

5. Hourfar, J.; Bister, D.; Kanavakis, G.; Lisson, J.A.; Ludwig, B. Influence of interradicular and palatal placement of orthodontic mini-implants on the success (survival) rate. Head Face Med. 2017, 13, 14. [CrossRef] [PubMed] 
6. Valladares-Neto, J.; Evangelista, K. Infrazygomatic mini-implant penetration into the maxillary sinus. Am. J. Orthod. Dentofac. Orthop. 2018, 154, 462-463. [CrossRef]

7. Moslemzadeh, S.H.; Sohrabi, A.; Rafighi, A.; Kananizadeh, Y.; Nourizadeh, A. Evaluation of interdental spaces of the mandibular posterior area for orthodontic mini-implants with cone-beam computed tomography. J. Clin. Diagn. Res. 2017, 11, ZC09-ZC12. [CrossRef]

8. Haddad, R.; Saadeh, M. Distance to alveolar crestal bone: A critical factor in the success of orthodontic mini-implants. Prog. Orthod. 2019, 20, 19. [CrossRef] [PubMed]

9. Hickey, J.C. The glossary of prosthodontic terms. J. Prosthet. Dent. 2005, 94, 10-92. [CrossRef]

10. Ramasamy, M.; Giri, R.R.; Subramonian, K.; Narendrakumar, R. Implant surgical guides: From the past to the present. J. Pharm. Bioallied Sci. 2013, 5 (Suppl. 1), S98-S102. [CrossRef]

11. Kalra, S.; Tripathi, T.; Rai, P.; Kanase, A. Evaluation of orthodontic mini-implant placement: A CBCT study. Prog. Orthod. 2014, 15, 61. [CrossRef] [PubMed]

12. Kapila, S.D.; Nervina, J.M. CBCT in orthodontics: Assessment of treatment outcomes and indications for its use. Dentomaxillofac. Radiol. 2015, 44, 20140282. [CrossRef]

13. Bae, S.-M.; Park, H.-S.; Kyung, H.-M.; Kwon, O.-W.; Sung, J.-H. Clinical application of micro-implant anchorage. J. Clin. Orthod. 2002, 36, 298-302. [PubMed]

14. Felicita, A.S. A simple three-dimensional stent for proper placement of mini-implant. Prog. Orthod. 2013, 14, 45. [CrossRef] [PubMed]

15. D'Souza, K.M.; Aras, M.A. Types of implant surgical guides in dentistry: A review. J. Oral Implantol. 2012, 38, 643-652. [CrossRef] [PubMed]

16. Pillai, S.; Upadhyay, A.; Khayambashi, P.; Farooq, I.; Sabri, H.; Tarar, M.; Lee, K.T.; Harb, I.; Zhou, S.; Wang, Y.; et al. Dental 3D-printing: Transferring art from the laboratories to the clinics. Polymers 2021, 13, 157. [CrossRef] [PubMed]

17. Simon, H.; Heather, J.C.; Lianshan, L.; Scott, L.; Wook, -J.S. Effect of surgical guide design and surgeon's experience on the accuracy of implant placement. J. Oral Implant. 2012, 38, 311-323.

18. Ravidà, A.; Barootchi, S.; Tattan, M.; Saleh, M.H.A.; Gargallo-Albiol, J.; Wang, H.L. Clinical outcomes and cost effectiveness of computer-guided versus conventional implant-retained hybrid prostheses: A long-term retrospective analysis of treatment protocols. J. Periodontol. 2018, 89, 1015-1024. [CrossRef] [PubMed]

19. Cassetta, M.; Altieri, F.; Di Giorgio, R.; Barbato, E. Palatal orthodontic miniscrew insertion using a CAD-CAM surgical guide: Description of a technique. Int. J. Oral Maxillofac. Surg. 2018, 47, 1195-1198. [CrossRef]

20. Barros, S.E.C.; Janson, G.; Chiqueto, K.; De Freitas, M.R.; Henriques, J.F.C.; Pinzan, A. A three-dimensional radiographic-surgical guide for mini-implant placement. J. Clin. Orthod. 2006, 40, 548-554.

21. Kim, S.-H.; Kang, J.-M.; Choi, B.; Nelson, G. Clinical application of a stereolithographic surgical guide for simple positioning of orthodontic mini-implants. World J. Orthod. 2008, 9, 371-382.

22. Suzuki, E.Y.; Buranastidporn, B. An adjustable surgical guide for miniscrew placement. J. Clin. Orthod. 2005, 39, 588-590.

23. Miyazawa, K.; Kawaguchi, M.; Tabuchi, M.; Goto, S. Accurate pre-surgical determination for self-drilling miniscrew implant placement using surgical guides and cone-beam computed tomography. Eur. J. Orthod. 2010, 32, 735-740. [CrossRef] [PubMed]

24. Morea, C.; Hayek, J.E.; Oleskovicz, C.; Dominguez, G.C.; Chilvarquer, I. Precise insertion of orthodontic miniscrews with a stereolithographic surgical guide based on cone beam computed tomography data: A pilot study. Int. J. Oral Maxillofac. Implantol. 2011, 26, 860-865.

25. Page, M.J.; McKenzie, J.E.; Bossuyt, P.M.; Boutron, I.; Hoffmann, T.C.; Mulrow, C.D.; Shamseer, L.; Tetzlaff, J.M.; Akl, E.A.; Brennan, S.E.; et al. The PRISMA 2020 statement: An updated guideline for reporting systematic reviews. BMJ 2021, 372, n71. [CrossRef]

26. Beller, E.M.; Glasziou, P.P.; Altman, D.G.; Hopewell, S.; Bastian, H.; Chalmers, I.; Gøtzsche, P.C.; Lasserson, T.; Tovey, D. PRISMA for abstracts: Reporting systematic reviews in journal and conference abstracts. PLoS Med. 2013, 10, e1001419. [CrossRef]

27. Rethlefsen, M.L.; Kirtley, S.; Waffenschmidt, S.; Ayala, A.P.; Moher, D.; Page, M.J.; Koffel, J.B. PRISMA-S: An extension to the prisma statement for reporting literature searches in systematic reviews. Syst. Rev. 2021, 10, 39. [CrossRef]

28. Higgins, J.P.T.; Thomas, J.; Chandler, J.; Cumpston, M.; Li, T.; Page, M.J. Cochrane Handbook for Systematic Reviews of Interventions, 2nd ed.; Welch, V.A., Ed.; John Wiley \& Sons: Chichester, UK, 2019.

29. Sackett, D.L.; Strauss, S.E.; Richardson, W.S.; Rosenberg, W.; Haynes, B.R. Evidence-Based Medicine: How to Practice and Teach EBM, 2nd ed.; Elsevier Churchill Livingstone: Philadelphia, PA, USA, 2000.

30. Hong, Q.N.; Fàbregues, S.; Bartlett, G.; Boardman, F.; Cargo, M.; Dagenais, P.; Gagnon, M.-P.; Griffiths, F.; Nicolau, B.; O'Cathain, A.; et al. The Mixed Methods Appraisal Tool (MMAT) version 2018 for information professionals and researchers. Educ. Inf. 2018, 34, 285-291. [CrossRef]

31. Del Re, A.C. A practical tutorial on conducting meta-analysis in R. Quant. Methods Psychol. 2015, 11, 37-50. [CrossRef]

32. Higgins, J.P.T.; Thompson, S.G. Quantifying heterogeneity in a meta-analysis. Stat. Med. 2002, 21, 1539-1558. [CrossRef] [PubMed]

33. Hein, J.L. Discrete Structures, Logic, and Computability, 2nd ed.; Jones and Bartlett Publishers, Inc.: Sudbury, MA, USA, 2002.

34. Suzuki, E.Y.; Suzuki, B. Accuracy of miniscrew implant placement with a 3-dimensional surgical guide. J. Oral Maxillofac. Surg. 2008, 66, 1245-1252. [CrossRef] [PubMed] 
35. Rashid, A.; El Feky, H.; Issa, N. Accuracy of miniscrew insertion using a customized printed three-dimensional surgical guide (a comparative split mouth study). Egypt. Dent. J. 2021, 67, 109-118. [CrossRef]

36. Kim, D. An Evaluation of Clinical Stability of Miniscrew with Surgical Guide Using Intraoral Scan Model and CBCT: Randomized Clinical Trial. Bachelor's Dissertation, Yonsei University, Seoul, Korea, 2019.

37. Bae, M.-J.; Kim, J.-Y.; Park, J.-T.; Cha, J.-Y.; Kim, H.-J.; Yu, H.-S.; Hwang, C.-J. Accuracy of miniscrew surgical guides assessed from cone-beam computed tomography and digital models. Am. J. Orthod. Dentofac. Orthop. 2013, 143, 893-901. [CrossRef]

38. Qiu, L.; Haruyama, N.; Suzuki, S.; Yamada, D.; Obayashi, N.; Kurabayashi, T.; Moriyama, K. Accuracy of orthodontic miniscrew implantation guided by stereolithographic surgical stent based on cone-beam CT-derived 3D images. Angle Orthod. 2012, 82, 284-293. [CrossRef]

39. Möhlhenrich, S.C.; Brandt, M.; Kniha, K.; Bock, A.; Prescher, A.; Hölzle, F.; Modabber, A.; Danesh, G. Suitability of virtual plaster models superimposed with the lateral cephalogram for guided paramedian orthodontic mini-implant placement with regard to the bone support. Eignung virtuell überlagerter Situationsmodelle und korrespondierender Fernröntgenseitenaufnahmen zur schablonengeführten Mini-Implantat-Insertion unter Berücksichtigung des Knochenangebots. J. Orofac. Orthop. 2020, 81, 340-349.

40. Möhlhenrich, S.C.; Brandt, M.; Kniha, K.; Prescher, A.; Hölzle, F.; Modabber, A.; Wolf, M.; Peters, F. Accuracy of orthodontic mini-implants placed at the anterior palate by tooth-borne or gingiva-borne guide support: A cadaveric study. Clin. Oral Investig. 2019, 23, 4425-4431. [CrossRef]

41. Kniha, K.; Brandt, M.; Bock, A.; Modabber, A.; Prescher, A.; Hölzle, F.; Danesh, G.; Möhlhenrich, S.C. Accuracy of fully guided orthodontic mini-implant placement evaluated by cone-beam computed tomography: A study involving human cadaver heads. Clin. Oral Investig. 2021, 25, 1299-1306. [CrossRef]

42. Altieri, F.; Cassetta, M. The impact of tooth-borne vs computer-guided bone-borne rapid maxillary expansion on pain and oral health-related quality of life: A parallel cohort study. Am. J. Orthod. Dentofac. Orthop. 2020, 158, e83-e90. [CrossRef]

43. Wilmes, B.; Vasudavan, S.; Drescher, D. CAD-CAM-fabricated mini-implant insertion guides for the delivery of a distalization appliance in a single appointment. Am. J. Orthod. Dentofac. Orthop. 2019, 156, 148-156. [CrossRef]

44. Malhotra, S.; Nanda, P.; Sidhu, M.S. A guide for simple mini-implant placement. Orthodontics 2012, 13, $166-167$.

45. Cousley, R.R.J. A stent-guided mini-implant system. J. Clin. Orthod. 2009, 43, 403-407.

46. Kim, S.-H.; Choi, Y.-S.; Hwang, E.-H.; Chung, K.-R.; Kook, Y.-A.; Nelson, G. Surgical positioning of orthodontic mini-implants with guides fabricated on models replicated with cone-beam computed tomography. Am. J. Orthod. Dentofac. Orthop. 2007, 131 (Suppl. 4), S82-S89. [CrossRef]

47. D'Haese, J.; Van De Velde, T.; Elaut, L.; De Bruyn, H. A prospective study on the accuracy of mucosally supported stereolithographic surgical guides in fully edentulous maxillae. Clin. Implantol. Dent. Relat. Res. 2012, 14, 293-303. [CrossRef]

48. Lee, J.-A.; Ahn, H.-W.; Oh, S.H.; Park, K.-H.; Kim, S.-H.; Nelson, G. Evaluation of interradicular space, soft tissue, and hard tissue of the posterior palatal alveolar process for orthodontic mini-implant, using cone-beam computed tomography. Am. J. Orthod. Dentofac. Orthop. 2021, 159, 460-469. [CrossRef]

49. Mallick, S.; Murali, P.S.; Kuttappa, M.N.; Shetty, P.; Nair, A. Optimal sites for mini-implant insertion in the lingual or palatal alveolar cortical bone as assessed by cone beam computed tomography in South Indian population. Orthod. Craniofac. Res. 2021, 24, 121-129. [CrossRef]

50. Möhlhenrich, S.; Heussen, N.; Modabber, A.; Bock, A.; Hölzle, F.; Wilmes, B.; Danesh, G.; Szalma, J. Influence of bone density, screw size and surgical procedure on orthodontic mini-implant placement_Part B: Implant stability. Int. J. Oral Maxillofac. Surg. 2021, 50, 565-572. [CrossRef]

51. Jedliński, M.; Mazur, M.; Grocholewicz, K.; Janiszewska-Olszowska, J. 3D scanners in orthodontics-Current knowledge and future perspectives-A systematic review. Int. J. Environ. Res. Public Health 2021, 18, 1121. [CrossRef]

52. Hong, S.-B.; Kusnoto, B.; Kim, E.-J.; BeGole, E.A.; Hwang, H.-S.; Lim, H.-J. Prognostic factors associated with the success rates of posterior orthodontic miniscrew implants: A subgroup meta-analysis. Korean J. Orthod. 2016, 46, 111-126. [CrossRef]

53. Gandhi, V.; Upadhyay, M.; Tadinada, A.; Yadav, S. Variability associated with mandibular buccal shelf area width and height in subjects with different growth pattern, sex, and growth status. Am. J. Orthod. Dentofac. Orthop. 2021, 159, 59-70. [CrossRef] [PubMed]

54. Suzuki, E.Y.; Suzuki, B.; Aramrattana, A.; Harnsiriwattanakit, K.; Kowanich, N. Assessment of miniscrew implant stability by resonance frequency analysis: A study in human cadavers. J. Oral Maxillofac. Surg. 2010, 68, 2682-2689. [CrossRef]

55. Kuroda, S.; Yamada, K.; Deguchi, T.; Hashimoto, T.; Kyung, H.-M.; Yamamoto, T.T. Root proximity is a major factor for screw failure in orthodontic anchorage. Am. J. Orthod. Dentofac. Orthop. 2007, 131, S68-S73. [CrossRef] [PubMed]

56. Chen, Y.J.; Chen, Y.H.; Lin, L.D.; Yao, C.C.J. Removal torque of miniscrews used for orthodontic anchorage-A preliminary report. Int. J. Oral Maxillofac. Implantol. 2006, 21, 283-289.

57. Askar, H.; Krois, J.; Rohrer, C.; Mertens, S.; Elhennawy, K.; Ottolenghi, L.; Mazur, M.; Paris, S.; Schwendicke, F. Detecting white spot lesions on dental photography using deep learning: A pilot study. J. Dent. 2021, 107, 103615. [CrossRef]

58. Ezhov, M.; Gusarev, M.; Golitsyna, M.; Yates, J.M.; Kushnerev, E.; Tamimi, D.; Aksoy, S.; Shumilov, E.; Sanders, A.; Orhan, K. Clinically applicable artificial intelligence system for dental diagnosis with CBCT. Sci. Rep. 2021, 11, 15006. [CrossRef] [PubMed] 